\title{
Recent Development of Si Chemical Dry Etching Technologies
}

Toshio Hayashi*

Plasma Nano Technology Research Center, Nagoya University, 464-8603, Japan

\begin{abstract}
Chemical dry etching in wafer processing was innovated and developed in 1976 using $\mathrm{CF}_{4} / \mathrm{O}_{2}$ downflow plasma for poly-Si etching. Thereafter, many researchers developed and reported various chemical dry etching methods.

Advanced Si chemical dry etching technology was developed in 2010, using $\mathrm{N}_{2}$ downflow plasma and $\mathrm{NF}_{3}$ flowing to the downflow plasma area. The etchant production mechanism for this technology was explained by us.

In these technologies, the plasma source is necessary to produce the etchants $\left(\mathrm{F}\right.$ for $\mathrm{Si}$ etching and $\mathrm{HF}+\mathrm{NH}_{3}$ for $\mathrm{SiO}_{2}$ etching).

Recently, a novel Si chemical dry etching technology was innovated and developed by us without plasma source, in which $\mathrm{F}$ atoms generated in $\mathrm{F}_{2}+\mathrm{NO} \rightarrow \mathrm{F}+\mathrm{FNO}$ reaction are used for Si etching in the pressure range of 100 to $1000 \mathrm{~Pa}$. The etch rate at room temperature is more than $5000 \mathrm{~nm} / \mathrm{min}$, and is dependent on the flow rate and on the distance between the gas mixing point and the wafer position. Increasing the substrate temperature, the minimum etch rate was obtained at $60^{\circ} \mathrm{C}$. Over this temperature, the etch rate increased again with increase of the substrate temperature. In the lower temperature region, the chemisorbed layer may be formed and the chemical reaction may be enhanced in this condensed layer. Increasing the temperature, this chemisorbed layer disappears around $60^{\circ} \mathrm{C}$. Over this temperature, the surface reaction mainly takes place according to Arrhenius equation.
\end{abstract}

\section{Keywords: Wafer processing; Dry etching}

\section{Introduction}

Chemical dry etching (CDE) in wafer processing was first developed by Horiike and Shibagaki [1], using $\mathrm{CF}_{4} / \mathrm{O}_{2}$ downflow plasma for poly-Si etching, to prevent the degradation of the electrical properties of integrated circuits (ICs) due to the bombardment of charged particles. Thereafter, many researchers developed and reported various chemical dry etching methods [2-11]. Mogab et al. [2] reported the $\mathrm{O}_{2}$ addition effect in $\mathrm{CF}_{4} / \mathrm{O}_{2}$ radial flow reactive plasma, in which the maximum $\mathrm{Si}$ etch rate was obtained at an $\mathrm{O}_{2}$ mixing ratio of $15 \%$. A similar phenomenon was observed in a planar capacitive coupled plasma reactor [12]. Flamm et al. [4] derived the regression equation of the $\mathrm{Si}$ etch rate observing the chemiluminescence from $\mathrm{SiF}_{3}{ }_{3}^{*}$ on the $\mathrm{Si}$ wafer and the etch rate as a function of the wafer temperature, and also showed that the reaction probability of $\mathrm{Si}$ with $\mathrm{F}$ was 0.00168 at room temperature. Ninomiya et al. [13] reported that the reaction probability of $\mathrm{Si}$ with $\mathrm{F}$ was 0.1 at $300 \mathrm{~K}$ by gas-phase titration method under careful treatment, avoiding surface oxidation by the ambient. Energetic beam induced $\mathrm{XeF}_{2}$ etching of $\mathrm{Si}$ was investigated by Coburn and Winters [14]. In this report, it was also suggested that the etch rate of $\mathrm{Si}$ by $\mathrm{XeF}_{2}$ gas without beam irradiation was $0.5-0.7 \mathrm{~nm} / \mathrm{min}$ (at flow rate of $\mathrm{XeF}_{2}=2 \times 10^{15} \mathrm{~mol} / \mathrm{s}$ ). The $\mathrm{O}_{2}$ addition effect in the planar capacitive coupled plasma reactor was clearly explained observing the negative ions emerged from etched Si surface [15]. In this experiment, it was confirmed that the etch rate decrease above the $15 \% \mathrm{O}_{2}$ mixing ratio was mainly due to surface oxidation, because the $\mathrm{C}_{2} \mathrm{~F}_{4}$ negative ion current observed by a mass spectrometer was approximately constant. $\mathrm{C}_{2} \mathrm{~F}_{4}$ molecules are generally formed on the wall surface and released from the surface, because $\mathrm{C}_{2} \mathrm{~F}_{4}$ molecule is very stable and $\mathrm{C}_{2} \mathrm{~F}_{4}$ ion is formed by thermal electron attachment with the energy of $0.5 \mathrm{eV}$ in the sheath region. In the $\mathrm{O}_{2}$ mixing ratio lower than $15 \%$, the etched surface was covered with $\mathrm{C}_{\mathrm{x}} \mathrm{F}_{\mathrm{y}}$ film. At around the maximum etching rate region, $\mathrm{C}_{x} \mathrm{~F}_{y}$ film was removed effectively by $\mathrm{O}$ atoms and ions, and therefore, $\mathrm{F}$ atoms might be consumed by reaction with $\mathrm{Si}$. Further increasing $\mathrm{O}_{2}$ concentration, the etched surface was partially covered with $\mathrm{SiO}_{\mathrm{x}}$ and $\mathrm{F}$ consumption decreased. This mechanism leads to the distinct maximum of $\mathrm{Si}$ etch rate and $\mathrm{F}$ concentration. Therefore, it is supposed that the similar phenomenon takes place on the Si etched surface in the $\mathrm{CF}_{4} / \mathrm{O}_{2}$ radial flow reactive plasma.

Thus, chemical dry etching technologies have been studied and developed, but have not been used in wafer fabrication as one of the major etching technologies, because the etch rate cannot be readily controlled, and/or no anisotropic etching profile is obtained. However, this technology turns into a very important one because the removal of damaged Si layer around the gate electrode and residual oxide layer after gate oxide are strongly required in the ultrafine pattern fabrication with a half pitch lower than $45 \mathrm{~nm}$. In these process, slow etch rate is required in order to control the etched depth of around $10 \mathrm{~nm}$, which is damaged by a prior reactive ion etching [16-18], or remains in a prior oxide etching.

\section{CDE Technologies with Long Life Time Plasma Source}

The plasma source is constituted by quartz or aluminum oxide tube for these remote plasma sources. Quartz tube is preferably used because recombination of produced hydrogen atoms [19] and fluorine atoms on the quartz tube inner wall is relatively lower. However, when fluorinecontaining compound is fed and decomposed in the discharge area, the quartz tube itself is eroded by fluorine containing plasma and has to be replaced with a new one after several hundred batches. If the fluorine containing etchants are produced outside the remote plasma source, the erosion of the plasma source is considerably reduced and the lifetime of the source material becomes longer owing to the reduction in the extent of fluorine erosion.

*Corresponding author: Toshio Hayashi, Plasma Nano Technology Research Center Nagoya University, 464-8603, Japan, E-mail: hayashi@plasma.engg.nagoya-u.ac.jp Received August 27, 2012; Accepted October 10, 2012; Published October 20 2012

Citation: Hayashi T (2012) Recent Development of Si Chemical Dry Etching Technologies. J Nanomed Nanotechol S15:001. doi:10.4172/2157-7439.S15-001

Copyright: (c) 2012 Hayashi T. This is an open-access article distributed under the terms of the Creative Commons Attribution License, which permits unrestricted use, distribution, and reproduction in any medium, provided the original author and source are credited. 
Chemical dry etching technology for native oxide removal by flowing $\mathrm{NF}_{3}$ to $\mathrm{H}_{2}+\mathrm{H}_{2} \mathrm{O}$ down flow plasma was first developed by Kikuchi et al. [20,21], to avoid damage to the quartz tube by plasma irradiation. In this process, $\mathrm{NF}_{3}$ is not decomposed in the plasma source. However, it is thought that the oxide layer is also removed through a similar etching mechanism in the $\mathrm{NF}_{3} / \mathrm{NH}_{3}$ down flow plasma on the wafer [8]. Oxide layer removal can also be carried out using $\mathrm{H}_{2}, \mathrm{~N}_{2}+\mathrm{H}_{2}$ or $\mathrm{NH}_{3}$ down flow plasma and $\mathrm{NF}_{3}$ flow without decomposition [22]. In these down flow plasmas, hot $\mathrm{H}$ atoms initiate the reaction with $\mathrm{NF}_{3}$ in the down flow area, and then successive reactions take place between $\mathrm{H}$ atoms and $\mathrm{NF}_{\mathrm{x}}(\mathrm{x}=1-2)$ [23]. Finally, $\mathrm{HF}$ and $\mathrm{NH}_{3}$ are produced and adsorbed on the wafer surface, proceeding to condensed phase on the wafer surface. In this condensed phase, a sort of ammonium fluoride etching in the liquid phase takes place. It was reported that the etch rate of the chemical dry etching method by flowing to the $\mathrm{H}_{2}, \mathrm{~N}_{2}+\mathrm{H}_{2}$, or $\mathrm{NH}_{3}$ down flow plasma was 1 to $10 \mathrm{~nm} / \mathrm{min}$ at the room temperature, not depending on the distance between the $\mathrm{NF}_{3}$ flow position and the wafer stage [22]. These processes are very useful to remove thin oxide layer (10 to $20 \mathrm{~nm}$ ) for the etching around the gate electrode without the plasma damage.

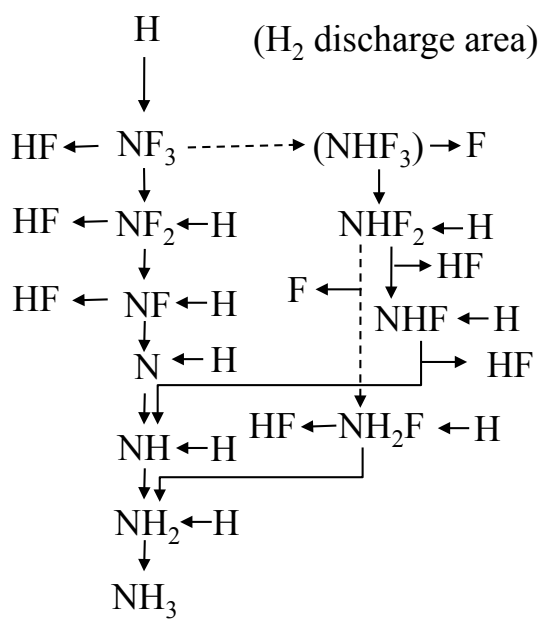

Figure 1: Deduced chemical reaction schemes of $\mathrm{NF}_{3}$ in $\mathrm{H}_{2}$ afterglow plasma.

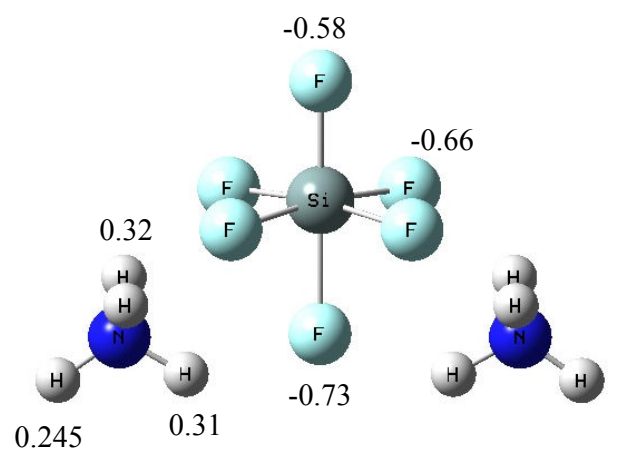

$\left(\mathrm{NH}_{4}\right)_{2} \mathrm{SiF}_{6}$

Figure 2: Stable molecular structure of etched product. The numerical values denote the charge density on the atoms.
The reaction mechanism for the thin oxide layer removal using $\mathrm{H}_{2}$ downflow plasma and flowing $\mathrm{NF}_{3}$ into this downflow plasma at around $500 \mathrm{~Pa}$ was clarified by us [23], in which backward flow of $\mathrm{NF}_{3}$ does not take place owing to viscous flow and $\mathrm{F}$ atom is not generated in the plasma source. The total reaction scheme is summarized and illustrated in Figure 1. The solid line shows the main reaction routes and the dashed line shows the minor reaction routes. Some of the reactions depicted in this figure also take place at the surface, because a strong hydrogen bond is formed between the $\mathrm{HF}$ and $\mathrm{NH}_{3}$ produced and the boiling point of this complex molecule exceeds $500 \mathrm{~K}$ [24]. Finally, $\mathrm{HF}$ and $\mathrm{NH}_{3}$ are formed and adsorbed on the wafer surface, on which a condensed phase is formed, so that a type of ammonium fluoride etching in the liquid phase takes place. Therefore, experimentally, by decreasing wafer temperature, etch rate increases, depending on temperature. Figure 2 shows the calculated molecular structure of $\left(\mathrm{NH}_{4}\right)_{2} \mathrm{SiF}_{6}$ formed on the $\mathrm{SiO}_{2}$ surface through the reaction

$$
\mathrm{SiO}_{2}+2 \mathrm{NH}_{3}+6 \mathrm{HF} \rightarrow(\mathrm{NH} 4)_{2} \mathrm{SiF}_{6}+2 \mathrm{H}_{2} \mathrm{O}
$$

This complex molecule with two $\mathrm{NH}_{4}$ groups on the same side is more stable than that with two $\mathrm{NH}_{4}$ groups on opposite sides to each other, because the coulomb interaction in $\mathrm{NH}_{4}-\mathrm{F}-\mathrm{NH}_{4}$ takes place and stabilizes the molecule. This complex molecule decomposes with an increase in the wafer temperature up to $373 \mathrm{~K}$ to release $\mathrm{SiF}_{4}$ and the white powder remains on the wafer surface, which was deduced as $\mathrm{FH}-$ $\mathrm{NH}_{3}-\mathrm{HF}$ (coordinate bonded $\mathrm{H}$ of $\mathrm{HF}$ with $\mathrm{N}$ of $\mathrm{NH}_{3}$ ) [8]. However, the total cohesive energy (hydrogen bond energy) between two HF and $\mathrm{NH}_{3}$ molecules is $-0.606 \mathrm{eV}$, which is lower than $-0.663 \mathrm{eV}$ of the hydrogen bond energy between $\mathrm{HF}$ and $\mathrm{NH}_{3}$ molecules in B3LYP/6$31+\mathrm{G}(\mathrm{d}, \mathrm{p})$ level. This implies that the white powder is not composed of only $\mathrm{FH}-\mathrm{NH}_{3}-\mathrm{HF}$ and should rather be a huge molecule composed of $\left(\mathrm{NH}_{4} \mathrm{~F}\right)_{\mathrm{n}}$. It was found from the molecular orbital calculation that the white powder was mainly composed of stratified $n\left(\mathrm{NH}_{4} \mathrm{~F}\right)_{3}$ with a $\mathrm{C}_{3}$ symmetry axis [23].

A Si etching technology using $\mathrm{NF}_{3}$ flow into $\mathrm{N}_{2}$ down flow plasma was found by Tajima and Takahashi [25], at the distance of $20-40 \mathrm{~cm}$ apart from the edge of the $\mathrm{N}_{2}$ plasma source. They reported that the etch rate strongly depended on the etching conditions of the $\mathrm{NF}_{3}$ and $\mathrm{N}_{2}$ flow rates at the pressure of 100 to $500 \mathrm{~Pa}$, by applying $2.45 \mathrm{GHz}$ microwave power of $1-2 \mathrm{~kW}$. In their report, the etch rate was especially dependent on the $\mathrm{N}_{2}$ flow rate ratio at the distance of $40 \mathrm{~cm}$; Si was not etched under a condition of the $\mathrm{N}_{2}$ and $\mathrm{NF}_{3}$ flow rates of 0.5 and 1 SLM, and increasing the $\mathrm{N}_{2}$ flow rate to 1 SLM Si was etched. This means that backward flow of $\mathrm{NF}_{3}$ does not take place (owing to viscous flow). This etch rate dependence on the $\mathrm{N}_{2}$ flow rate ratio is very useful to remove the damaged $\mathrm{Si}$ layer of approximately $10 \mathrm{~nm}$ around gate electrode [16-18], where clean removing the damaged layer without any etched residues is required, and is also to be controllable within 1 to 2 minutes by changing the $\mathrm{N}_{2}$ flow rate ratio.

Figure 3 shows a schematic diagram of the reaction chamber, in which $\mathrm{NF}_{3}$ is fed $20-40 \mathrm{~cm}$ from the edge of the discharge area at pressures of $100-500 \mathrm{~Pa}$ [26]. Under this condition, $\mathrm{NF}_{3}$ is fed into the downflow area without decomposition and reacts with activated $\mathrm{N}$ atoms, and/or activated $\mathrm{N}_{2}$ molecules, and three-body reactions partially take place because of the short mean free path (order of $\mu \mathrm{m}$ ) of molecules in viscous flow. The total flow rate is several liters/min under standard conditions and the flow rate ratio of $\mathrm{N}_{2}$ to $\mathrm{NF}_{3}$ is 0.5 to 1.0, which is deduced from the overall reaction scheme of

$\mathrm{N}_{2}+2 \mathrm{NF}_{3} \rightarrow 2 \mathrm{~N}_{2}+6 \mathrm{~F}$

In the experimental aspects, the absolute density of $\mathrm{N}_{2}\left(\mathrm{~A}^{3} \Sigma \mathrm{u}^{+}\right)$, 


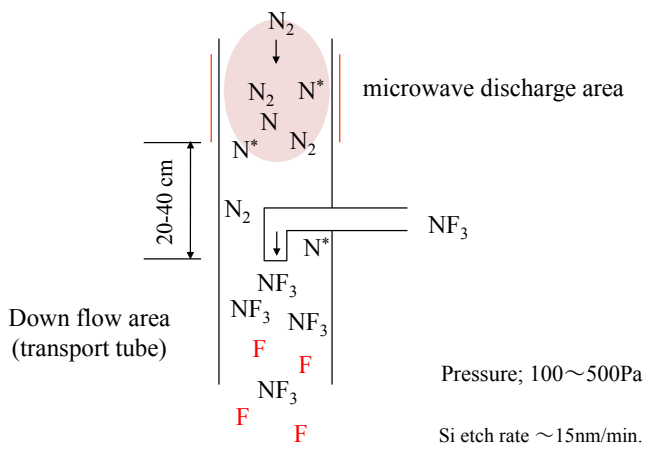

$\mathrm{nN}+\mathrm{mNF}_{3} \rightarrow 4 \mathrm{~F}+\mathrm{Si} \rightarrow \mathrm{SiF}_{4}$

Figure 3: Schematic diagram of Si chemical dry etching system.

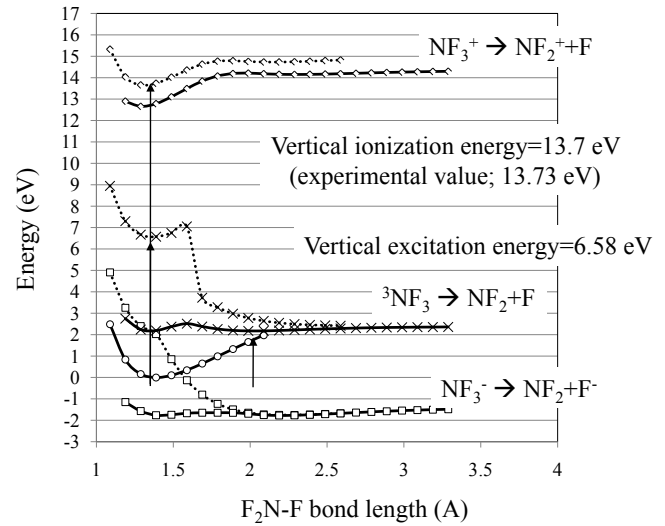

Figure 4: The calculated potential curves of $\mathrm{NF}_{3}$ for the ground state, the negative ion state, the lowest triplet state, and the ionized state, obtained by using B3LYP/6-311G(d) and 6-31+G(d).

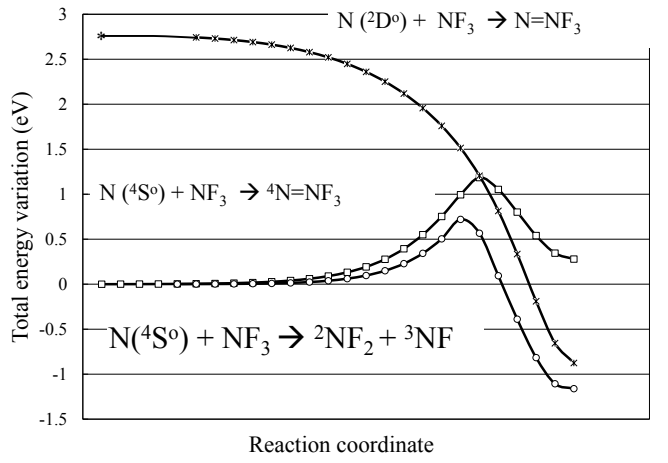

Figure 5: $\mathrm{N}+\mathrm{NF}_{3}$ reaction potentials as a function of reaction coordinate.

$\mathrm{N}\left({ }^{4} \mathrm{~S}_{\mathrm{o}}\right)$ and $\mathrm{N}\left({ }^{2} \mathrm{D}_{\mathrm{o}}\right)$ in an inductively coupled nitrogen plasma source were measured by cavity-ringdown and vacuum ultraviolet absorption spectroscopy by Horikawa et al. [27]. It was shown in this report that the densities of the above mentioned three active species at 20 mTorr were almost the same and that the densities of active nitrogen atoms did not change with an increase in the pressure up to 100 mTorr, whereas the density of $\mathrm{N}_{2}\left(\mathrm{~A}^{3} \sum \mathrm{u}^{+}\right)$decreased as the pressure increased. In the theoretical aspect, the rate constant for the $\mathrm{NF}_{3}+\mathrm{N}\left({ }^{4} \mathrm{~S}_{\mathrm{o}}\right) \rightarrow \mathrm{NF}_{2}+\mathrm{NF}$ gas phase reaction was calculated using the transition state theory based on MP2/6-31G(d) of the Gaussian 03 program by Barreto et al. [28], to explain the growth kinetic mechanism of boron nitride films. No other theoretical investigations are found. Therefore, we calculated the $\mathrm{N}+\mathrm{NF}_{\mathrm{x}}(\mathrm{x}=1$ to 3 ) reactions using a molecular orbital method to clarify the $\mathrm{F}$ production mechanism in $\mathrm{N}_{2}$ downflow plasma and flowing $\mathrm{NF}_{3}$.

Figure 4 shows the potential curves of $\mathrm{NF}_{3}$ for the ground state, the negative ion state and the ionized state with $\mathrm{C}_{3 \mathrm{~V}}$ structure, calculated using the B3LYP/6-311G(d). The lowest triplet state was calculated using B3LYP/6-31+G(d) and superimposed on this figure, because the lowest triplet state is a Rydberg state. The calculated energies for these states are good agreements with the experimental ones [29,30]. The calculated vertical transition energy to the lowest triplet state is 6.58 $\mathrm{eV}$. This energy is very close to the $\mathrm{N}_{2}\left(\mathrm{~A}^{3} \Sigma \mathrm{u}^{+}\right)$energy (approximately 7 $\mathrm{eV})$ [31]. This means that the following energy transfer reaction takes place resonantly:

$\mathrm{N}_{2}\left(\mathrm{~A}^{3} \sum \mathrm{u}+\right)+\mathrm{NF}_{3}(1 \mathrm{~A} 1) \rightarrow \mathrm{N}_{2}\left(\mathrm{X}^{1} \sum \mathrm{g}+\right)+\mathrm{NF}_{3}\left(3 \mathrm{E}_{1}\right) \rightarrow \mathrm{N} 2\left(\mathrm{X}^{1} \sum \mathrm{g}^{+}\right)+\mathrm{NF}_{2}+\mathrm{F}$

Figure 5 shows $\mathrm{N}+\mathrm{NF}_{3}$ reaction potentials as a function of reaction coordinate. The following three reaction schemes are possible:

$$
\begin{aligned}
& \mathrm{N}\left({ }^{4} \mathrm{~S}_{\mathrm{o}}\right)+\mathrm{NF}_{3} \rightarrow{ }^{2} \mathrm{NF}_{2}+{ }^{3} \mathrm{NF} \Delta \mathrm{E}_{\mathrm{a}}=0.72 \mathrm{eV} \Delta \mathrm{E}_{\mathrm{H}}=-1.16 \mathrm{eV}(2) \\
& \mathrm{N}\left({ }^{4} \mathrm{~S}_{\mathrm{o}}\right)+\mathrm{NF}_{3} \rightarrow{ }^{4} \mathrm{~N}=\mathrm{NF}_{3} \Delta \mathrm{E}_{\mathrm{a}}=1.2 \mathrm{eV} \Delta \mathrm{E}_{\mathrm{H}}=+0.28 \mathrm{eV}(3) \\
& \mathrm{N}\left({ }^{2} \mathrm{D}_{\mathrm{o}}\right)+\mathrm{NF}_{3} \rightarrow{ }^{2} \mathrm{~N}=\mathrm{NF}_{3} \Delta \mathrm{E}_{\mathrm{a}}=0 \mathrm{eV} \Delta \mathrm{E}_{\mathrm{H}}=-3.6 \mathrm{eV}(4)
\end{aligned}
$$

Where $\Delta \mathrm{E}_{\mathrm{a}}$ is activation energy (reaction barrier) and $\Delta \mathrm{E}_{\mathrm{H}}$ is reaction enthalpy, obtained by $\mathrm{B} 3 \mathrm{LYP} / 6-31+\mathrm{G}(\mathrm{d})$. Negative value means exothermic energy. The calculated result for the reaction scheme (2) is almost the same with that obtained by Barreto et al. [28]. The temperature of atomic nitrogen estimated from the spectra taken at 14 $\mathrm{cm}$ from the DC discharge area at $100 \mathrm{~Pa}$ was estimated as $0.2580 \mathrm{eV}$ for pure $\mathrm{N}_{2}$ plasma [32]. Therefore, it is considered that the reaction (4) is only possible for $\mathrm{N}+\mathrm{NF}_{3}$ reaction. The calculated state energy of $\mathrm{N}_{(}\left(\mathrm{D}_{\mathrm{o}}\right)$ was approximately $2.75 \mathrm{eV}$ above the ground state energy of $\mathrm{N}\left({ }^{4} \mathrm{~S}_{\mathrm{o}}\right)$ in B3LYP/ 6-31+G(d) level, slightly larger than the experimental energy difference of $2.38 \mathrm{eV}$ [31].

The total reaction scheme is summarized and illustrated in Figure 6. The solid line shows the main reaction routes and the dashed line shows the minor reaction routes. Surveying Figure 6 and the aforementioned reaction schemes, it is thought that the electron attachment dissociation can be neglected because the electrons produced in the plasma cannot survive at the $\mathrm{NF}_{3}$ flowing point $(20-40 \mathrm{~cm}$ apart from the discharge

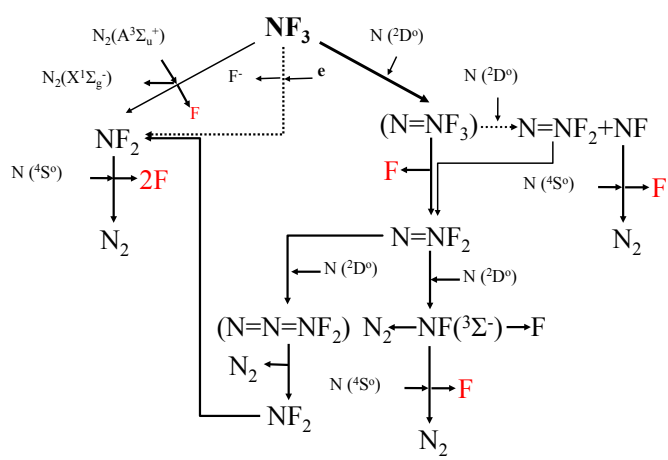

Figure 6: The total reaction schemes obtained by B3LYP/6-31+G(d) 
area in the pressure range of 100 to $500 \mathrm{~Pa}$ ). Similarly, it is deduced that the contribution of $\mathrm{N}_{2}\left(\mathrm{~A}^{3} \Sigma_{\mathrm{u}}^{+}\right)$is not so high, because the density of $\mathrm{N}_{2}\left(\mathrm{~A}^{3} \Sigma_{\mathrm{u}}^{+}\right)$decreases as the pressure increases, whereas the density of $\mathrm{N}\left({ }^{2} \mathrm{D}^{\circ}\right)$ was not dependent on the pressure (20-100 mTorr), according to the results shown by Horikawa et al. [27]. Therefore, the main reactions should be initiated by $\left.\mathrm{N}^{2} \mathrm{D}_{0}\right)$. Then, $\mathrm{NF}\left({ }^{3} \Sigma^{-}\right)$and/or $\mathrm{NF}_{2}$ radicals are produced in the down flow area. $\mathrm{NF}$ and $\mathrm{NF}_{2}$ radicals are very unstable, so these radicals easily react with ground state nitrogen atoms $\mathrm{N}\left({ }^{4} \mathrm{~S}_{0}\right)$, proceeding to $\mathrm{N}_{2}$ molecule and $\mathrm{F}$ atom(s). Decreasing the distance between the discharge region and the $\mathrm{NF}_{3}$ flowing position, $\mathrm{Si}$ etch rate increases [25] because the densities of $\mathrm{N}_{2}\left(\mathrm{~A}^{3} \Sigma_{\mathrm{u}}^{+}\right)$, and electrons also increase.

\section{CDE Technology without Plasma Source}

Chemical dry etching in view of gas-surface chemistry was first studied by Coburn and Winters [14]. In this work, they found that ion irradiation plays a very important role to enhance surface chemical reaction of $\mathrm{XeF}_{2}$ with $\mathrm{Si}$. This means that bond breaking of Si-Si and dangling bond formation enhances the surface chemical reaction. They also suggested that the purely chemical etch rate by $\mathrm{XeF}_{2}$ was $0.5-0.7$ $\mathrm{nm} / \mathrm{min}$ at room temperature at the flow rate of $\mathrm{XeF}_{2}=2 \times 10^{15} \mathrm{~mol} / \mathrm{s}$ (corresponding to approximately $600 \mathrm{~nm} / \mathrm{min}$ at $2.7 \mathrm{sccm}$ ), without ion irradiation. The surface chemistry of $\mathrm{F}$ atoms with $\mathrm{Si}$ was further investigated by Flamm et al. [4], using $\mathrm{F}_{2}$ downflow plasma. They observed the relation between the etch rate and chemiluminescence, emitted from $\mathrm{SiF}_{3}{ }^{*}$ produced by $\mathrm{SiF}_{2}+\mathrm{F}$ reaction near the $\mathrm{Si}$ surface, and proposed the surface chemical reaction model that a layer of $\mathrm{SiF}_{2}$ groups was chemically bound to the Si surface and the rate determinant reaction of impinging $\mathrm{F}$ atoms with $\mathrm{Si}_{-} \mathrm{SiF}_{2}$ bonds of the chemisorbed layer controlled the gasification of $\mathrm{Si}$ as $\mathrm{SiF}_{2}$ and higher fluorinated species. Ibbotson et al. [5] studied surface chemical reactions of $\mathrm{XeF}_{2}$ and $\mathrm{F}$ atoms with $\mathrm{Si}$, in pressure range of 0.05 to 2 Torr. They clarified that the chemical reaction of $\mathrm{XeF}_{2}$ with $\mathrm{Si}$ was different from that of $\mathrm{F}$ atom with $\mathrm{Si}$. In the case of $\mathrm{F}$ atom, the etch rate was fit to a general form of the Arrhenius equation, as a function of substrate temperature, whereas an Arrhenius plot of the $\mathrm{XeF}_{2}$ etch rate data exhibited a complex behavior. Below $450 \mathrm{~K}$, the etch rate decreased with increasing temperature, between 360 and $450 \mathrm{~K}$, it reached a minimum, and finally at higher temperatures it increased. They concluded that physisorbed and condensed $\mathrm{XeF}_{2}$ layers contributed to the reaction rate below $450 \mathrm{~K}$ temperature region. Similar phenomena were observed

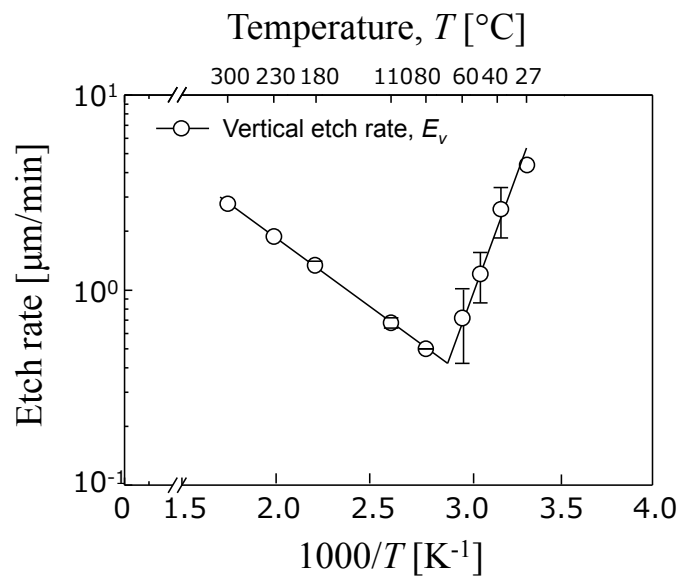

Figure 7: Etch rate was high at room temperature (RT) and decreased with $T$ at $T<60^{\circ} \mathrm{C}$ and increased with $T$ at $T>60^{\circ} \mathrm{C}$. for inter-halogen compounds, such as $\mathrm{ClF}_{3}, \mathrm{BrF}_{3}$ and $\mathrm{IF}_{5}$ with $\mathrm{Si}$ [6]. The common properties of these compounds may be having relatively weak bond energy and heavy weight mass. The bond energy of $\mathrm{F}_{2}$ is also very low $(1.8 \mathrm{eV}[33])$. The low bond energy means very reactive with $\mathrm{Si}$, because Si-F bond energy is very high (approximately $6 \mathrm{eV}[34]$ ). The molecules with heavy mass have an inter-molecular force (Van der Waals forces), so the adsorption readily takes place on $\mathrm{Si}$ and then bond distortion may take place due to strong Si-F bond energy, resultantly leading to Si etching.

These gases, therefore, are very interesting to etch $\mathrm{Si}$ without any plasma source. However, the running cost is too high to respond to requirement of mass production lines.

\section{New CDE System without Plasma Source}

A new silicon etching process was innovated by us, using $\mathrm{F} 2+\mathrm{NO} \rightarrow \mathrm{F}+\mathrm{FNO}$ reaction [35], in the pressure region of 100 to $1000 \mathrm{~Pa}$. This technology receives much attention for etching process engineers, in view of the initial and the running costs. The etch rate was comparable with that obtained using $\mathrm{XeF}_{2}$ chemical dry etching. Arrhenius plot of the etch rate data obtained in the $\mathrm{F}_{2}+\mathrm{NO}$ mixing gas exhibited a complex behavior [36], similar to $\mathrm{XeF}_{2}$ etching. Below 430 $\mathrm{K}$, the etch rate decreased with increasing temperature, it reached a minimum between 430 and $450 \mathrm{~K}$, and finally at higher temperatures it increased. The etch rate as a function of the substrate temperature is shown in Figure 7.

In the feasibility experiments [35,36], A $6 \mathrm{~mm}$ (width) $\times 15 \mathrm{~mm}$ (length) $\times 0.53 \mathrm{~mm}$ (thickness) $\mathrm{Si}$ sample was placed on the ceramic heater, which was covered by the $\mathrm{Al}$ foil inserted in the Pyrex tube with the inner diameter of $25 \mathrm{~mm}$ and the length of $150 \mathrm{~mm}$. The Si sample was exposed to the gas mixture of $\mathrm{NO}$ at a flow rate of $5 \mathrm{sccm}$ $\left(8.5 \times 10^{-3} \mathrm{~Pa}-\mathrm{m}^{3} / \mathrm{s}\right)$ diluted with $\mathrm{Ar}$ at a flow rate of $49.5 \mathrm{sccm}\left(8.4 \times 10^{-2}\right.$ $\left.\mathrm{Pa}-\mathrm{m}^{3} / \mathrm{s}\right)$, and $\mathrm{Ar} / 5 \%-\mathrm{F}_{2}$ at a flow rate of $54.5 \mathrm{sccm}\left(9.2 \times 10^{-2} \mathrm{~Pa}-\mathrm{m}^{3} / \mathrm{s}\right)$. The corresponding $\mathrm{F}_{2}$ flow rate was $2.7 \mathrm{sccm}\left(4.6 \times 10^{-3} \mathrm{~Pa}-\mathrm{m}^{3} / \mathrm{s}\right)$. In this study, the temperature on the ceramic heater was adjusted between $27^{\circ} \mathrm{C}$ and $300^{\circ} \mathrm{C}$ by the variable autotransformer, while measuring the temperature by the K-type thermocouple placed on top of the ceramic heater under the Si substrate. Pressure in the Pyrex tube was maintained at $600 \mathrm{~Pa}$ throughout the process time of $0.5 \sim 5 \mathrm{~min}$. Base pressure of this chamber was maintained at $\sim 10^{-1} \mathrm{~Pa}$ by the dry pump, so the small amount of $\mathrm{H}_{2} \mathrm{O}$ was considered to be remained in the chamber.

Two Si samples were prepared. One was p-type Si (100) sample with the resistivity of $\sim 1000 \Omega$-cm with a $1 \mu$ m-thick $\mathrm{SiO}_{2}$ mask layer that had $8 \mu \mathrm{m} \times 8 \mu \mathrm{m}$ square patterns. This sample was exposed in NO and $\mathrm{F}_{2}$ gases for $5 \mathrm{~min}$. for the etch rate and the etched profile analysis. The other was the non-doped Si (100) sample with the resistivity of $>3000$ $\Omega$-cm for the surface morphology and the surface chemical bonding structure analysis. This sample was cleaned with acetone, ethanol, deionized (DI) water, $13 \%$ hydrochloric acid and $49 \%$ hydrofluoric (HF) acid for $5 \mathrm{~min}$, followed by rinsing in DI water for $<5 \mathrm{~s}$ to terminate the $\mathrm{Si}$ surface with $\mathrm{H}$. This $\mathrm{H}$-terminated $\mathrm{Si}$ sample was exposed to $\mathrm{NO}$ and $\mathrm{F}_{2}$ gases for $0.5 \mathrm{~min}$ in the aforementioned process chamber.

Figure 8 shows the representative cross-sectional SEM images of the patterned p-type $\mathrm{Si}(100)$ samples placed in $\mathrm{NO}$ and $\mathrm{F}_{2}$ gases, when the Si was heated at $27^{\circ} \mathrm{C} \sim 300^{\circ} \mathrm{C}$. We found that the etched $\mathrm{Si}$ surface was very rough when the substrate temperature was $27^{\circ} \mathrm{C}$, and increasing the temperature up to $70^{\circ} \mathrm{C}$, the etch rate decreased and the roughness also decreased. Nanoporous features were observed in the microscopically rough etched profile at this temperature range. When 


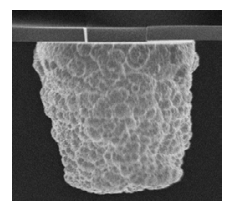

$\mathrm{Ts}=27^{\circ} \mathrm{C}$

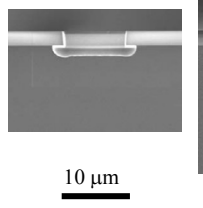

$\mathrm{Ts}=80^{\circ} \mathrm{C}$

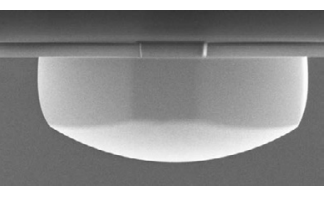

$\mathrm{Ts}=300^{\circ} \mathrm{C}$

Figure 8: Etched profiles under the same condition at different substrate temperatures $\left(\mathrm{T}_{\mathrm{s}}\right)$.

(a) $\quad \mathrm{T}_{\mathrm{s}}=27^{\circ} \mathrm{C}$

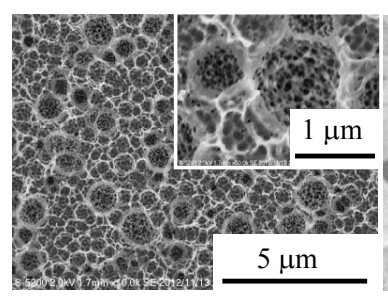

Figure 9: Etched surfaces at $27^{\circ} \mathrm{C}$ and $230^{\circ} \mathrm{C}$ for non-doped $\mathrm{Si}(100)$

the Si sample was heated at $60^{\circ} \mathrm{C} \sim 230^{\circ} \mathrm{C}$, the etched bottom surface became smooth with the absence of nanoporous features. The etch rate decreased with increase of the temperature up to $\sim 70^{\circ} \mathrm{C}$ and increased again at above $70^{\circ} \mathrm{C}$. When the substrate temperature was adjusted at above $230^{\circ} \mathrm{C}$, the sidewall of the etched profile became vertical. The crystallographic orientation was observed from these SEM images where the bottom surface was $\{100\}$ and the sidewall was $\{110\}$. Corner undercutting with the exposure of $\{211\}$ and $\{411\}$ were also observed at the corner of the etched profile [36].

Thus, morphology of the etched bottom surface and the sidewall surface of the p-doped $\mathrm{Si}$ was dramatically changed when the $\mathrm{Si}$ was heated at different temperatures. Figure 9 shows the top view of the $\mathrm{Si}$ (100) placed in the NO and $\mathrm{F}_{2}$ gases for $0.5 \mathrm{~min}$. The microscopically rough etched profile were observed, similarly when the Si was chemically dry etched in $\mathrm{XeF}_{2}$ or $\mathrm{ClF}_{3}$ gases $[5,6]$. Previous studies stated that the evolution of the rough surface was due to the chemisorption of not only $\mathrm{F}$ but also $\mathrm{XeF}_{2}, \mathrm{XeF}, \mathrm{ClF}_{3}, \mathrm{Cl}_{2}, \mathrm{Cl}$ that would etch Si differently. The residence time of those molecules on the $\mathrm{Si}$ surface was long when the substrate temperature was low. The high Si etch rate at the low temperature in $\mathrm{NO}$ and $\mathrm{F}_{2}$ gases observed in Figure 8 and 9 can be explained by the presence of the chemisorbed $\mathrm{F}_{2}, \mathrm{~F}$ and others that would promote the etching. In addition to $\mathrm{F}_{2}$ and $\mathrm{F}, \mathrm{NO}$ would inhibit the etching by capping the dangling bonds. FNO would act as both a promoter and an inhibitor of the Si etching process by producing and capping the dangling bonds at the surface. These multiple reactions between molecules in the gas phase and the Si surface induced not only microscopically rough etched profile, but also produced complex porous features at low temperature.

The formation of the anisotropic etched profile at $27^{\circ} \mathrm{C}$ shown in Figure $8 \mathrm{a}$ has never been observed when the Si was chemically dry etched in $\mathrm{XeF}_{2}$ or $\mathrm{ClF}_{3}$ gases. The formation of this anisotropic etched profile was produced probably due to the chemisorptions of $\mathrm{NO}$, FNO, $\mathrm{OH}$, and $\left(\mathrm{SiF}_{4}\right)(\mathrm{FNO})_{2}$ at the sidewall. $\left(\mathrm{SiF}_{4}\right)(\mathrm{FNO})_{2}$ coordinated compound is weakly bounded molecule with intermolecular force of $0.34 \mathrm{eV}$ in B3LYP/6-311+G(d) level. This energy is comparable with that of intermolecular hydrogen bond energy of $\mathrm{H}_{2} \mathrm{O}-\mathrm{H}_{2} \mathrm{O}$ (approximately
$0.2 \mathrm{eV})$. The boiling point of $\left(\mathrm{SiF}_{4}\right)(\mathrm{FNO})_{2}$ was reported as $80^{\circ} \mathrm{C}$ [37]. The contribution of $\left(\mathrm{SiF}_{4}\right)(\mathrm{FNO})_{2}$ to prevent sidewall etching at a low temperature still needs further investigation by utilizing in-situ gas and surface analysis techniques.

In conclusion, $\mathrm{Si}$ chemical dry etching was performed in $\mathrm{NO}$ and $\mathrm{F}_{2}$ gases using the exothermic reaction of $\mathrm{F}_{2}+\mathrm{NO} \rightarrow \mathrm{F}+\mathrm{FNO}$. The formation of nanoporous features, the initiation of the flat surface and the orientation dependent etched profile were observed by controlling the temperature of the Si substrate between $27^{\circ} \mathrm{C}$ and $300^{\circ} \mathrm{C}$. The chemisorbed $\mathrm{F}, \mathrm{F}_{2}$ and $\mathrm{FNO}$ promoted Si etching by forming new dangling bonds, while $\mathrm{NO}, \mathrm{OH}$ and FNO inhibited etching by terminating the dangling bond at the $\mathrm{Si}$ surface at low temperature. The multiple chemical reactions between the molecules in the gas phase and the Si surface occurred at different rates, leading to produce complex nanoporous features in microscopically rough etched profiles. The reduction of $\mathrm{F}, \mathrm{F}_{2}, \mathrm{FNO}$ and large molecules in the chemisorbed layer decelerated the etch rate at an intermediate temperature. When the substrate temperature was ramped at above $230^{\circ} \mathrm{C}$, the $\mathrm{Si}$ etching was mainly performed by $\mathrm{F}, \mathrm{F}_{2}$ and $\mathrm{FNO}$ at the $\mathrm{Si}$ surface, and contribution of NO and the large coordinated compound could be ignored. The crystallographic orientation was evolved and the etch rate increased with the temperature by the increase of the rate constant of $F_{,} F_{2}$ and FNO and the Si surface.

\section{Summary}

The development of the chemical dry etching technologies is reviewed historically in this literature. The downflow chemical dry etching technology using $\mathrm{CF}_{4} / \mathrm{O}_{2}$ is now available to fabricate LSI and power devices. The chemical dry etching technology using $\mathrm{XeF}_{2}$ without plasma is widely used in the field of micro electro-mechanical system (MEMS) fabrication process. The $\mathrm{N}_{2}$ downflow plasma and $\mathrm{NF}_{3}$ flow system is considered to be a new damage less process after the poly-Si gate etching, to remove ion damaged layer of $10 \mathrm{~nm}$. The chemical dry etching using $\mathrm{ClF}_{3}$ gas is considered as a candidate to reduce reflectance of solar cell devices. Thus, the chemical dry etching technologies are selectively used according to adaptable application area.

The chemical dry etching technology in $\mathrm{F}_{2}+\mathrm{NO}$ gas mixture is considered as a most promising candidate to be applicable to a wide variety of devices, because of its low initial and running costs and the changeable surface morphology depending on the substrate temperature. The sacrificial layer removal for MEMS devices and the surface texturing for solar cell devices can be carried out at room temperature with the rate of several $1000 \mathrm{~nm} / \mathrm{min}$. The damaged layer removal after wafer thinning by the chemical-mechanical polishing (CMP) method for 3 dimensional devices is also capable and anticipated as the most promising technology. This process can be carried out using the ramp technology of the substrate temperature; high rate etching is used in the initial stage and low rate etching with smooth surface is used in the final stage.

\section{References}

1. Horiike Y, Shibagaki M (1976) A new chemical dry etching. Jpn J Appl Phys supple 15:13-18.

2. Mogab CJ, Adams AC, Flamm DL (1978) Plasma etching of $\mathrm{Si}$ and $\mathrm{SiO}_{2}$-The effect of oxygen additions to CF4 plasmas. J Appl Phys 49: 3796-3803.

3. Flamm DL, Mogab CJ, Sklaver ER (1979) Reaction of fluorine atoms with $\mathrm{SiO}_{2}$ J Appl Phys 50: 6211-6213.

4. Flamm DL, Donnelly VM, Mucha JA (1981) The reaction of fluorine atoms with silicon. J Appl Phys 52: 3633-3639. 
5. Ibbotson DE, Flamm DL, Mucha JA, Donnelly VM (1984) Comparison of $\mathrm{XeF}_{2}$ and F-atom reactions with $\mathrm{Si}$ and $\mathrm{SiO}_{2}$. Appl Phys Lett 44: 1129-1131.

6. Ibbotson DE, Mucha JA, Flamm DL, Cook JM (1984) Plasmaless dry etching of silicon with fluorine-containing compounds. J Appl Phys 56: 2939-2942.

7. Suto S, Hayasaka N, Okano $H$, Horiike $Y(1989)$ Highly selective etching of $\mathrm{Si}_{3} \mathrm{~N}_{4}$ to $\mathrm{SiO}_{2}$ employing fluorine and chlorine atoms generated by microwave discharge. J Electrochem Soc 136: 2032-2034.

8. Nishino $\mathrm{H}$, Hayasaka N, Okano $\mathrm{H}$ (1993) Damage-free selective etching of $\mathrm{Si}$ native oxides using $\mathrm{NH}_{3} / \mathrm{NF}_{3}$ and $\mathrm{SF}_{6} / \mathrm{H}_{2} \mathrm{O}$ down-flow etching. J Appl Phys 74 $1345-1348$.

9. Kastenmeier BEE, Matsuo PJ, Oehrlein GS, Langan JG (1999) Silicon etching in $\mathrm{NF}_{3} / \mathrm{O}_{2}$ remote microwave plasmas. J Vac Sci Technol A 17: 3179.

10. Tsuji M, Okano S, Tanaka A, Nishimura Y (1999) Chemical dry etching of S substrate in a discharge flow using Ar/CF4 gas mixtures. Jpn J Appl Phys 38: 6470 .

11. Yun YB, Pak SM, Kim DJ, Lee NE, Choi CK, et al. (2008) Thin Solid Films 516 3549.

12. Coburn JW, Chen M (1980) Optical emission spectroscopy of reactive plasmas: A method for correlating emission intensities to reactive particle density. J Appl Phys 51: 3134-3136.

13. Ninomiya K, Suzuki K, Nishimatsu S, Okada O (1985) Reaction of atomic fluorine with silicon. J Appl Phys 58: 1177-1182.

14. Coburn JW, Winters HF (1979) Ion- and electron-assisted gas-surface chemistry-An important effect in plasma etching. J Appl Phys 50: 3189-3196.

15. Hayashi T, Murai S, Sato F, Kono A, Mizutani N, et al. (2011) Measurement of negative ions generated on the Si etched surface. Jpn J Appl Phys 50: 08KB018KB04.

16. Ohchi T, Kobayashi S, Fukasawa M, Kugimiya K, Kinoshita T, et al. (2008) Reducing damage to Si substrates during gate etching processes. Jpn J Appl Phys 47: 5324.

17. Eriguchi K, Ono K (2008) Quantitative and comparative characterizations of plasma process-induced damage in advanced metal-oxide-semiconductor devices. J Phys D 41: 024002.

18. Nakakubo Y, Matsuda A, Fukasawa M, Takao Y, Tatsumi T, et al. (2010) Optical and electrical characterization of hydrogen-plasma-damaged silicon surface structures and its impact on in-line monitoring. Jpn J Appl Phys 49: 08JD0208JD06.

19. Grubbs RK, George SM (2006) Attenuation of hydrogen radicals traveling under flowing gas conditions through tubes of different materials. J Vac Sci Technol A 24: 486-496.

20. Kikuchi J, Suzuki M, Fujimura S, Yano $\mathrm{H}$ (1993) Effects of $\mathrm{H}_{2} \mathrm{O}$ on atomic hydrogen generation in hydrogen plasma. Jpn J Appl Phys 32: 3120

21. Kikuchi J, Iga M, Ogawa H, Fujumura S, Yano H (1994) Native oxide removal on $\mathrm{Si}$ surfaces by $\mathrm{NF}_{3}$ - added hydrogen and water vapor plasma downstream treatment. Jpn J Appl Phys 33: 2207-2211.
22. Inoue H, Higuchi Y, Suu K (2011) Private communication

23. Hayashi T, Ishikawa K, Sekine M, Hori M, Kono A, et al. (2012) Quantum chemical investigation for chemical dry etching of $\mathrm{SiO}_{2}$ by flowing $\mathrm{NF}_{3}$ into $\mathrm{H}_{2}$ downflow plasma. Jpn J Appl Phys 51: 016201.

24. Verrcke G, Schaekers M, Verstraete K, Arnauts S, Heyns MM, et al. (2000) J Electrochem Soc. 147: 1499

25. Tajima Y, Takahashi S (2011) Japan Patent JP2010165954 and private communication.

26. Hayashi T, Ishikawa K, Sekine M, Hori M, Kono A, et al. (2012) Quantum Chemical Investigation of Si Chemical Dry Etching by Flowing $\mathrm{NF}_{3}$ into $\mathrm{N}_{2}$ Downflow Plasma. Jpn J Appl Phys 51: 026505.

27. Horikawa Y, Kurihara K, Sasaki K (2010) Absolute Densities of $\mathrm{N}_{2} \mathrm{~A}_{3} \Sigma_{u}+$ ) $\mathrm{N}\left({ }^{4} \mathrm{So}\right)$, and $\mathrm{N}\left({ }^{2} \mathrm{Do}\right)$ in an Inductively Coupled Nitrogen Plasma Source. Jpn $J$ Appl Phys 49: 026101.

28. Barreto PRP, Vilela AFA, Gargano R, Ramalho SS, Salviano LR (2006) $\mathrm{NF}_{3}+\mathrm{N}=\mathrm{NF}_{2}+\mathrm{NF}$ rate constant calculated using $\mathrm{TST}$ with simple tunneling correction J Mol Struct: Theochem 769: 201-205.

29. Bassett PJ, Lloyd DR (1970) Chem Phys Lett 6: 166.

30. Kalyuzhnaya AG, Ryabtsev AV, Shchedrin Al (2008) Electron energy distribution function in a hollow-cathode glow discharge in mixtures of nitrogen with electronegative gases. Tech Phys 48: 38-42.

31. Steinfeld JI (1985) Molecules and radication: An introduction to modern molecular spectroscopy. ( $2^{\text {nd }}$ Ed. $)$, New York, USA 106.

32. Suraj KS, Bharathi P, Prahlad V, Mukherjee S (2007) Near cathode optical emission spectroscopy in $\mathrm{N}_{2}-\mathrm{H}_{2}$ glow discharge plasma. Surf Coat Technol 202: 301-309.

33. Jones WE, Skolnik EG (1976) Reactions of fluorine atoms. Chem Rev 76: 563 592.

34. Fisher ER, Kickel BL, Armentrout PB (1993) Collision-induced dissociation and charge-transfer reactions of SiFx+ $(x=1-4)$. Thermochemistry of SiFx and SiFx+. J Phys Chem 97: 10204-10210.

35. Tajima S, Hayashi T, Ishikawa K, Sekine M, Hori M (2013) Room-temperature S etching in $\mathrm{NO} / \mathrm{F}_{2}$ gases and the investigation of surface reaction mechanisms. J Phys Chem C117: 5118-5125.

36. Tajima S, Hayashi T, Ishikawa K, Sekine M, Hori M (2013) $5^{\text {th }}$ Intern. Symp. Adv. Plasma Sci. Appl. Nitrides and Nanomaterials (ISPLASMA) 187

37. Kigoshi A (1975) Differential scanning calorimetry study of complex fluorides of zirconium, tin, vanadium, silicon, antimony, molybdenum and tellurium. Thermochimica Acta 12: 179-187. 